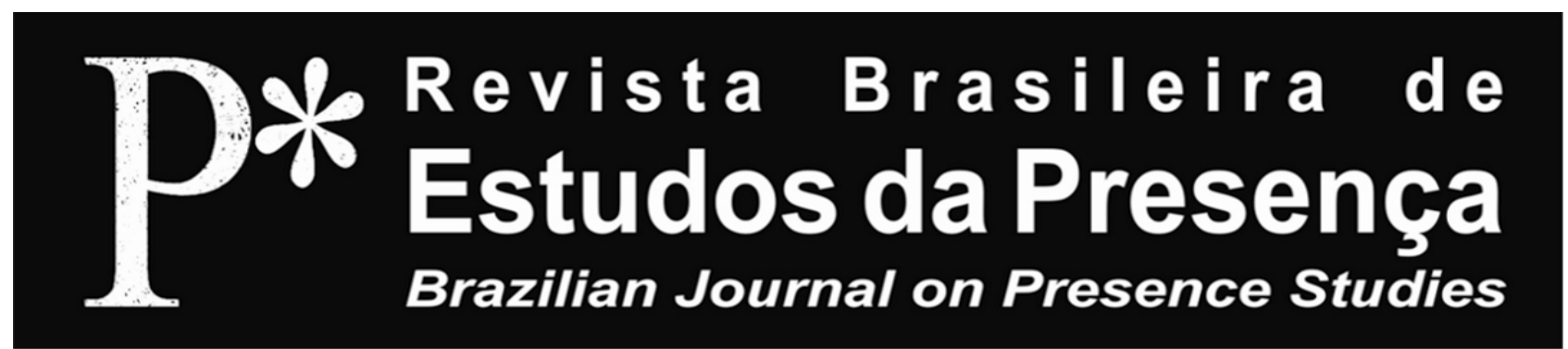

CONTEMPORARY TOPICS II

E-ISSN 2237-2660

\title{
Dancing the Urban Heritage
}

\author{
Juliana Raposo Semeghini \\ 'Universidade Estadual de Campinas - UNICAMP, Campinas/SP, Brazil
}

\begin{abstract}
Dancing the Urban Heritage - This article proposes to broaden the discussion of the threatened identity of the Urban Heritage, perceived within a culture of body reification, from the viewpoint of ephemeral arts. The ongoing research, from which this article derives, is interested in investigating authors who question documental representations, who recover forgotten cultural spaces and who propose a review of historical memory. The analysis of works that trace the genealogy of this ethnographic turn in art history contributed to the understanding of an artistic practice based on the sensitive world, related to its surroundings, in addition to providing clues about the artist capable of summoning others to a new kind of public experience.
\end{abstract}

Keywords: Urban Heritage. Contextual Art. Artist who Connects. Performative Program.

RÉSUMÉ - Danser le Patrimoine Urbain - Cet article propose un élargissement de la discussion sur l'identité menacée du Patrimoine Urbain, perçu dans une culture de la réification du corps, à partir des arts éphémères. La recherche en cours, dont dérive cet article, s’intéresse à enquêter sur des auteurs qui questionnent les représentations documentaires, qui récupèrent des espaces culturels oubliés et qui proposent une révision de la mémoire historique. L'analyse des œuvres qui retracent la généalogie de ce tournant ethnographique de l'histoire de l'art a contribué à la compréhension d'une pratique artistique fondée sur le monde sensible et située par rapport à son environnement, en plus d'offrir des indices sur ce genre d'artiste capable d'appeler l'autre à un nouveau sorte d'expérience publique. Mots-dés: Patrimoine Urbain. Art Contextuel. Artiste Connecteur. Programme Performatif.

RESUMO - Dançar o Patrimônio Urbano - Este artigo propóe um alargamento da discussáo da identidade ameaçada do Patrimônio Urbano, percebido dentro de uma cultura de reificaçáo do corpo, a partir do ponto de vista das artes efêmeras. A pesquisa em processo, da qual deriva o artigo, interessa-se em investigar autores que questionam as representaçóes documentais, que recuperam espaços culturais esquecidos e que propóem uma revisão da memória histórica. A análise de trabalhos que traçam a genealogia dessa virada etnográfica na história da arte contribuiu para compreensão de um fazer artístico fundado sobre o mundo sensível e situado em relaçáo ao seu entorno, além de oferecer pistas sobre o artista capaz de convocar o outro para um novo tipo de experiência pública. Palavras-chave: Patrimônio Urbano. Arte Contextual. Artista Conector. Programa Performativo. 


\section{First Clues}

In the final years of my undergraduate program in the School of Architecture and Urban Design, when I gained a contextualized understanding of my artistic practice, I began to formulate questions from the simple understanding that my hands can be an extension of my memory to write, draw, sculpt a scale model, and that the importance of this bodily dimension would not be explored to its full potential in classes that taught students to create new projects. The questions became more pressing when the architectural programs of the surroundings where the objects of our interventions would be located were based on assumptions made at a distance. Added to this is yet another layer of complexity: the moment when historical discussions about urban and cultural heritage, perceived in all their breadth and as part of a living fabric, impose themselves as a starting point for the relations of planning and growth of cities.

Where to start to understand the challenge of investigating these territories of memory and what kind of project interventions can we propose for places with such specific and mobile dynamics?

From the question of how to position oneself in relation to the disciplines of architecture and urban heritage, I carry the undergraduate experience and repertoire as a choice to go on a journey. Shaping the knowledge imbricated in my artistic practice and updating theories, including those related to the history of urbanism, heritage and restoration, using theories exogenous to the area. As suggested by Sylvie Fortin and Pierre Gosselin (2014), in Consideraçôes metodológicas para a pesquisa em arte no meio acadêmico [Methodological Considerations for Research in the Arts within Academia], as a researcher-artist, I present in this article an accumulation of vestiges from my ongoing research, welcoming subjectivities while narrating the encounters that happened along the way.

In writing this paper, I am less concerned with delving into the theoretical-historical issues of heritage and more concerned with narrating the movement of my body when attempting to grapple with the issue from a new perspective. I approach authors who trace the genealogy of an ethnographic turn in the arts, that is, who map artistic creations that question documental representations, recover forgotten cultural spaces, propose a re- 
view of historical memory and already view architecture as living phenomenon. As such, I start out from the work A alegoria do patrimônio [The Allegory of Heritage], by Françoise Choay (2006), which presents a historical overview in which the investigation of these territories of memory raises provocative questions on how to actually incorporate them into the cities' dynamics, considering their preexistences and changing desires linked to the organic memory of those who daily experience it. Choay maps the huge gap between the invention of the historical monument during the cultural changes of the $15^{\text {th }}$ century in Italy - when a restricted part of the elite began to recognize in Classical Antiquity the supremacy of the text over the ancient monuments and their ruins, which should be preserved as witnesses of the great authors - to the construction of the recent notion of urban heritage ${ }^{1}$.

Looking at architectural design and urban heritage through the lens of performative cultural actions and from a participatory perspective, this gesture can become a political act that harbors urgent needs of construction, housing, the yearnings of immaterial knowledge and, also, the gaps in recreating spaces-to-come of an urban project. To this end, I meet Suely Rolnik's perspective on the current sociocultural war, which tries to deprive us of daily contact with our body's desires and her view on the power of participatory invitations by an artist like Lygia Clark (Rolnik, 2018), so as to try to understand an artistic practice founded on the sensitive world and related to its surroundings, which proposes poetic shelters that enable the body to support its precarious condition as it actively moves over the world's topological surface. Texts by Francesco Careri (2017), Paul Ardenne (2006) and Óscar Cornago (2019) assist in searching for words capable of denominating this artistic practice that opens spaces for encounters with the Other and risks encouraging the multiplicities of cultural actions. Amid these theoretical examples, I narrate the choreography of an encounter that took place at the beginning of my artistic practice as a researcher and that, although very brief, raised questions about alterity as a mobilizing factor in artistic production. It devises a symbol-image for Rolnik's reflection on active cut as a creative power in Lygia Clark's Caminhando [Walking] proposal. Finally, as a transient conclusion, I reflect on what comes after the despite of, drawing on the poetic glimpse of Georges Didi-Huberman for small luminous dots of micropolitical manifestations of resistance in 
dark times (Didi-Huberman, 2011). I also expect to contribute to the writing of an essay whose literary images sharpen the complexity of an artistic production that brings its processes closer to the studies of presence and contextual art, recognizing dance and theater as expanded fields.

\section{Allegory of Urban Heritage}

In her book $A$ alegoria do patrimônio [The Allegory of Heritage], Françoise Choay (2006) presents an investigation that places the understanding of historical heritage at the center of a reflection on the fate of today's society. She discusses the first moments when the monuments could be seen from a historical distance, when preservation choices became based on a well-founded project, to then explain the context in which researchers focused their attention on the morphology and dynamics of cities, resulting in the emergence of the expression urban heritage and the general conception of space as territory, where elements of the urban fabric are interconnected. This scenario is outlined to emphasize how the notion of urban heritage is fairly recent, lagging 400 years behind the invention of the historical monument, according to Choay. The historic city remained - and remains today - an obstacle to cleansing urbanization processes, while the notion of space was as absent as the understanding of the heterogeneous totality of a city to be preserved in its entirety.

The culture industry also appropriated historical heritage, which becomes part of tourist trails that expand its audience. The process of appreciating urban space, governed by the real estate market, stipulates values that are recognizable and ends up determining how users relate to the city. The notion of surplus value plays the spatial role of breaking with the unproductive inertia of heritage until it becomes consumable. Historical buildings are demolished due to urban plans of social cleansing and downtown gentrification, or plans that prioritize wide roads and car access. Other buildings are rebuilt with no scientific basis and with architectural styles unrelated to local history, but which satisfy and attract tourists. Facilities are installed and additions are made to give buildings a completely new appearance without clearly indicating all modern interventions. Often, the new functions of heritage after local revitalization are incompatible with the preservation of its physical integrity. 
The investigation on urban heritage territories and their representations in the collective imagination pose great challenges for intervention projects in spaces with very specific, diverse and changing internal memories and dynamics. A systematization of experiences restricted to the field of architecture is unable to yield spatial and socio-cultural solutions for the debate on architectural heritage and restoration.

\section{Body-to-Body Crossing}

In As regras do jogo: a ação sociocultural em teatro e o ideal democrático [The Rules of the Game: Socio-cultural action in theater and the democratic ideal], Suzana Viganó (2006) articulates her discourse around Hannah Arendt's critical thinking, when describing the current cultural situation, in which she places her own struggle, fostered by an educational project of theatrical action in the Recanto Primavera community, in Morumbi, a neighborhood in Sáo Paulo, Brazil (2002). A training project running counter to a mass culture which needs to produce an abundance of objects that can be easily consumed and assimilated - from the supremacy of homo laborans, rather than one capable of creating and recreating his place in the world (Viganó, 2006, p. 24). That was the term used by Hannah Arendt to describe this new type of individual who, despite being overinformed, is indifferent and whose only task corresponds to maintaining the body's biological processes. Choay, on the other hand, invents an analogous name: homo sapiens protheticus, to characterize the subject with a high capacity for abstraction, who established a new mediatized type of social relationship that expands to the relationship with the city, now virtualized. Part of the logic of consumption, urban heritage is perceived within the development of a culture of the body based on its reification, a body that has lost the capacity for symbolization and cultivates only what can be abbreviated. The city space, which could be a dynamic allegory, is passively observed, becoming a thing before an equally objectified body. In passively looking at the city, only the image of a material body is recognized on its surface. Taking the liberty of deepening Choay's metaphor, homo sapiens protheticus probably catalogued his past just as the culture industry crystallized urban heritage, both as dead properties.

Homo sapiens protheticus is the same individual who made up the board of advisers of the Sáo Paulo state body Conselho de Defesa do Patri- 
mônio Histórico, Arqueológico, Artístico e Turistico (Council for the Defense of Historical, Archaeological, Artistic and Tourist Heritage - CONDEPHAAT), and who voted approving the project by the Silvio Santos group to build towers of over thirty stories on the plot adjacent to Teatro Oficina (October 23, 2017); who was responsible for the administrative negligence that burned down the National Museum (Rio de Janeiro, September 2, 2018); who announced the cuts of $30 \%$ in the resources invested in Brazilian federal universities, ironically justified by the poor performance in the humanities departments and by the deviant behavior of researchers (announced at the end of April 2019 and marked by one of the largest organized mobilizations, a strike against the undermining and commercialization of public education in the country, on May 15, 2019); who called for and engaged in compiling an inventory of conservative artists to constitute a privileged choir; who threatens structures such as Fundação Nacional de Artes (Brazilian Arts Foundation - Funarte) and Agência Nacional do Cine$m a$ (Brazilian Film Agency - Ancine) with censorship, financing only what conforms to the government's ideological endorsement; and who celebrates the termination of policies offering protection to marginalized groups using the Latin expression Deus vult, meaning that something happened due to god's will - a decontextualized cry that strips the history of the Middle Ages of its complexities and generates a political-ideological unity marked by the ignorance and prejudice of new far-right groups. The individual who dons the stereotype of medieval armor replaces interconnected knowledge with the absolute unity of a military, male, white and Christian howl (Pachá, 2019). He has something artificial adjusted to the body that separates its gestures from the direct link with memory and expels it from the sphere of living discourse, unable to (re)create the present from a dialectic with the dreams of the past (Desgranges, 2015, p. 104-105).

Choay (2006) mentions the associations that people impart to the monument, such as parades and dramatic representations, to value it, blaming such events for transforming the monuments into theater or scene, as she describes, eventually removing their autonomy. The author possibly makes this comparison without considering the procedural character of theater, understanding it only as a product of cultural animation, or as a spectacle. Unmediated reincorporation of the monument to contemporary daily life may be studied by ephemeral art devices such as theater and dance, always 
renewing itself in action or in situation, and including the reader in the process discoveries. It is in the arts of presence that cultural action - action able to propose the conditions for a certain group to explore its own creative tools and move towards a process genuinely guided by its own intentions - finds the most fruitful opportunity to take place. The performative game makes it possible to recognize the aesthetic process, the cultural language and the equipment that serve the process itself, thus creating the possibility to recognize spaces for reflection, transformation and confrontation, and promoting body awareness in space (subjectivity and representation) and awareness of the collective and its surroundings (Coelho, 1981, p. 8687).

Choay also establishes a metaphor that defines the endangered identity of heritage and the new type of media-based relationship that we have developed with it: the mirror metaphor. Defined by a type of passive contemplation as an object of worship on whose surface one would recognize the very image of a merely material body, lacking power to symbolize. Faced with this reality, the only solution would be to go through this mirror.

This crossing may only be possible through our body. It passes, precisely, through a body-to-body action: that of the human body with the patrimonial body. The former must mobilize and alert all its senses, reestablish the authority of touch, cenesthesia, kinesthesia, hearing and smell, and refuse, at the same time, the hegemony of the eye and the seductions of the photographic or digital image. The latter would have a propaedeutic role: to make the three dimensions of human space, its scales, interconnections, contextualization, apprehended or relearned during the crossings, incursions and paths comparable to the knowledge of the organic memory, now ignored by the educational institution, which allowed old students to appropriate their literary heritage (Choay, 2006, p. 256-257, our translation) ${ }^{2}$.

The mirror transposition promoted by the author indicates a path that the discipline of urban design and architecture alone cannot handle if it is conceived as an isolated work. The encounter with the city requires recognizing this act as a political act. André Lepecki quotes Hannah Arendt and her understanding that "[...] a properly restored notion of politics must have the characteristics not of art in general, but more specifically of ephemeral arts: dance and theater" (Lepecki, 2013, p. 44, our translation) ${ }^{3}$. It is, therefore, possible to appropriate the word heritage by the inseparable link between architecture and urban design and theater and dance, keeping 
it alive and integrated into the urban fabric, the starting point between relationships at all times renewed. By observing heritage through the eyes of performance, we can recognize architecture and the urbanization process as practices, events and behaviors, and not as objects or things. Thus, at first, we reflect on the need to distinguish the dynamics of the ephemeral arts from the intention to build something that is permanently definitive, a building that remains immobile, tectonic, and ages intact as planned since the architectural program. From that moment, which resists the need for distinction, until the day we may use the term architecture without worrying whether it fits this political dimension, expanding its meaning to something that is experienced in the body, especially in educational spaces. Politics is only made, from a performative perspective, when each one is offered materials to create their own cartographic tracks, which generate new and subsequent tracks, engendering a process of recognition and discoveries of active subjects.

\section{Beyond the Mirror: a subjective out-of-subject experience}

Suely Rolnik's rehearsed words (2018) in Esferas da insurreição: notas para uma vida não cafetinada [The Spheres of Insurrection: Suggestions for combating the pimping of life] may contribute to further Choay's mirror metaphor. We analyze Rolnik's own example: Lygia Clark's proposition in the Caminhando [Walking] experiment. From a strip of paper joined at the ends, giving one end a half-twist, a Möbius strip appears, from which one cannot determine what is inside and what is outside. With scissors, it is possible to make a cut and finish it in the same place, or follow the instruction of the proposing artist and never end the cycle by making a new cut in a place other than the starting point. The former gesture results in a strip like the first one and nothing changes except for its thickness, as if the gesture were neutral and had no effect. By following the complete instructions, cutting becomes an active act, avoiding the first points to continue cutting and producing a difference in the shape of the strip and in the space that it creates. Experience becomes one of the ways to show, in practice, to those who join the game a means to access their particular creative power, to be reappropriated whenever necessary, protecting their inventive autonomy. Pedagogically, as suggested by Ana Maria Rodriguez Costas (2011) in her essay Abrigos poéticos [Poetic Shelters], Clark's proposals consider "[...] the con- 
struction of an environment that includes the implicit risks to divers in the deep layers of the body, from where expressiveness emerges, to the processes of exposure of oneself and to the Other, to being together, to looking for a new gesture, in a group" (Costas, 2011, p. 12, our translation) ${ }^{4}$. Lygia inaugurates, therefore, "[...] a sensitive architecture, in which gestures become as if poetic shelters, '[...] where to live is equivalent to communicate"” (Clark, 1980 apud Costas, 2011, p. 13, our translation) ${ }^{5}$, or to create knowledge together.

Based on Clark's project, Rolnik then proposes that we engage in a fabulation exercise and project the strip over the surface of the world, imagining a "[...] topological surface made of all types of bodies (human and non-human), in varied and variable connections" (Rolnik, 2018, p. 49). If the cut is a vigorous action, its active subject is inscribed in the sphere of the living discourse of history, where several paradoxical forces write it and inscribe its body in its course.

In the first chapter of this recent publication, as well as in the text Fale com ele ou como tratar o corpo vibrátil em coma [Talk to Him or How to Treat the Vibrating Body in a Coma], Rolnik (2003) describes the colonialcapitalist regime in an interpretation close to the integrated world capitalism proposed by Félix Guattari, in the late 1970s, to designate the processes of capital financialization that rendered it so agile and volatile as to colonize the world - requiring mobility in all its folds, including the politics of desire, expropriating life itself.

In the subjectivities under the domain of the colonial-capitalist unconscious, as its experiences as a subject are reduced, a reactive micropolitics prevails: the movement to preserve the forms of existence in which life is embodied in the present tends to prevail to a greater or lesser extent. This is because, dissociated from its condition of human being and unaware of the continuous process of mutation proper to the vital dynamics (driving dynamics, in the human), subjectivity lives under the pressure of the embryos of the world as threats of disintegration of itself and its existential field, since 'this world', the one in which the subject lives and in which it is structured, is lived by subjectivity as 'the world', unique and absolute. Under these conditions, to regain balance, desire clings to established forms, which it seeks to preserve at any cost. The greater the destabilization, the more vehement the subjectivity builds a fortress around what is instituted and defends it with all its might, possibly reaching high levels of violence to ensure its permanence - including the concrete elimination of any other than its mirror and whose 
existence has the effect of shaking faith in the universality of its world (Rolnik, 2018, p. 113-114, our translation) ${ }^{6}$.

To traverse the topological surface of the world means to live with tensions that push us towards the shattering of creative subjectivity itself, in addition to those that push us towards the creation of new worlds whose seeds arise even from the action of deconstructing rules ingrained in our body. It is not by chance that the text Performance e precariedade [On Precariousness and Performance], by Eleonora Fabião (2011), converges with Rolnik's description, written after the author came across the term precariousness in Lygia Clark's work, who composes sensory objects and biological architectures to teach psychophysical practices to her students. Attempts to fuse memory and time, producing the experience of the place. "Together we investigate ways to create a body; ways of existing; to co-exist, to 'learn to live on the basis of precariousness"' (Fabiáo, 2011, p. 64, our translation) ${ }^{7}$. Clark's proposals assert themselves as a memory of the actual body, aware that it is possible to withstand the precarious and destabilizing condition of its recreations and the new of ways of existing. She recognizes the precariousness of the body as a power by understanding it in opposition to the organized body, against crystallization of time and in favor of endless and paradoxical forces, of incomplete stories and engagements that are not ends in themselves.

The body, in which the trauma of deterritorializations driven by the seeds of new worlds are not metabolizable, consumes someone else's words and ready places in which it can act. The novel Fahrenheit 451, by Ray Bradbury (2012 [1953]), depicts this situation with Mildred, wife of the protagonist Montag, who spends her days filling in the gaps of a closedscript soap opera with pre-established lines, when she finally feels the comfort of belonging to that fictional family, within a stable setting.

As Choay proposed the mirror metaphor to frame the subject-heritage relationship at the end of her book, this would be a good opportunity to further it. When subjectivity is reduced to the subject, the city is just a mirror reflecting the individual. The urban heritage would then be diluted in this reflection, making it impossible to appropriate what is outside the subject, as he is unable to perceive and distinguish, always avoiding constructions (Coelho, 1981, p. 21) and encouraging only what can be consumed from this false narcissistic encounter. To cross the mirror means to perceive 
which forces conceived us and to be involved in a subjective out-of-subject experience. "In the subjective out-of-subject experience, the Other effectively lives in our body, through affections: effects of their presence in us", and "[...] when they enter our body, the forces of the world merge with the forces that animate it and, in this encounter, fertilize it" (Rolnik, 2018, p. 111 , our translation $)^{8}$. Beyond the mirror, the living constructions of the city's active memory can live in our bodies due to the affections that their latent reality produces in our life.

\section{Encounter as a Form of Time: an invitation to dance the free span of MASP}

Based on the interest in uniting this theoretical narrative about a contemporary artistic production capable of provoking displacements of the real, creating spaces of enunciation related to an exercise of enjoyment of the city, and given the possibility of breaking layers of mediation when engaging in a body-to-body dialogue with the urban space, I report my first practical experience as a proponent, or as someone who invites.

Most of my artistic inquiries began to materialize during the final project of the Graduate program in Performing Arts, at Escola Superior de Artes Célia Helena (Célia Helena Center for Arts and Education), supervised by Joana Dória. This work proposed to investigate the territories of the free span of Museu de Arte de São Paulo (Museum of Art of São Paulo MASP) and its representation in the urban collective imagination. It thus presented an occupation methodology that experimented with performative programs.

I invited friends and students of the school's undergraduate program to participate in six morning sessions, which occurred between January 29 and February 9, 2018, and perform with me artistic programs that I developed, aimed at relating the recognition of the body, the collective, and the surroundings of the free span of MASP. We sought to investigate the possibilities afforded by this void designed by Lina Bo Bardi - whether it was in fact a void, what its pre-existences were, and what the voices of the participants' personal projects were. To this end, we employed a conception of methodology beyond the replicable method, embracing what is produced along the way and contains enough gaps to continue reinventing itself in the process. Based on artistic performances and poetic references that mir- 
rored MASP's space, I collected cards with a series of performative programs to be carried out in groups. Therefore, an action plan was drawn up as a moving map. The programs, which were performed according to the research needs, were called floating programs.

I would like to develop, in a literary way, an outline for the experience occurred on February 2, 2018. The account of the events that occurred during that field day narratively incorporates the speech of the artists and researchers who joined in conversation after the experience: Debora Rebecchi, Emilie Becker, Irene Catunda, Isadora Madsen, Maitê Arouca, and Raíra Rosenkjar. Not transcribed as in a report, but crafted in metaphors, since the account was a personal experience. Given the memory of dancing the floating program proposed that day, I focus on the brief choreography of an encounter I experienced, attempting to expand in meaning a fragment-event that occurred during the process, as fleeting as it is essential to embody the driving issues of how I position myself as an artist, shared in this article.

On February 2, 2018, I invited the group of women to dance two concurrent floating programs in the freestanding space of MASP, to experience being in this non-fixed territory, feeling the historical weight of the Portuguese pavement, and the weight of the floor above us, the gallery floor. Before arriving at the museum, we watched the movie The Very Eye of Night (1958), directed by Maya Deren, a fifteen-minute short film in which the director makes everything inside the frame dance from the editing, including the space. The camera becomes a dance partner for the dancers and Deren shifts the images of gesture-impulses over a background of the universe's depth, which is also always shifting. The director's choices free all dancers from the force of gravity. Imbued with this sum of possibilities, in which the blurring of boundaries and spaces between members emerged from the encounter of floating bodies, we choreographed the following directions:

Dance giving in to gravity and mark your movements with charcoal on the sheet of paper horizontally; and

Dance paying attention to your body's ability to create voids.

Then, over a piece of kraft paper, a surface disorganized by the wind and everything that was swept up from the floor, like small pieces of glass, 
we danced. We danced searching for the dubious and abstract places of the directions. If one gives in completely to gravity, one falls to the ground, and perceives what remains in a still dance; when giving in and observing, one gives in to the surrounding social choreography. Close to the ground, the eye can look for other choreographies. If I choose parts of my body to give in and others to resist, I dance from new vectors. It is also possible to dance relating to the surroundings, mirroring the movement of those who walk and inhabit the sounds of the street: the man walking with a crutch defying the gaps in the Portuguese pavement unbalances me; the flapping of the dove's wings draws attention to the shoulder blades; one could react to the force coming from the accumulated rainwater, which fell abruptly from the slab onto the water mirror, giving in to the events of the surroundings. Charcoal was used to mark the choreography on paper. Due to its ephemeral quality, the gesture needed not to be recorded in its entirety, but only as suggestion.

The situation narrated below lasted five minutes or less. Time is measured outside the productive order that generates consumable products; it is unproductive time, spent and built in the body towards creation:

As we danced, I noticed that a group of teenagers observed the performance with great curiosity and commented on its possible meanings. I decided to raise my hand holding out the charcoal and ask if anyone would like to try. One of them volunteered; I explained that we were dancing giving in to gravity, and I showed it with my own body, while he watched me attentively.

I fall as I explain:

Just let go of the body, fall on the paper without worrying about its limits, and mark this movement spontaneously.

We fell and got up together three times, his body so remarkably close to mine that small gaps formed between us.

When the movement was over, he offered the charcoal to his friends while enthusiastically inviting them to try, giving new names to this fall as he explained it. They rejected the invitation claiming they were afraid of getting their clothes dirty, while they cleaned their friend's white shirt.

He left after we thanked each other.

In this very brief event, which emerged from the initiative to occupy the free span of MASP, a moment in which I live a metaphor together with the one I just met, our legs stumbled when encountering the other but 
boldly abandoned the usual upright posture, even if the fall elicited touches and required the body to recover once, twice, thrice. When the weight of the floor-slab of the MASP collection affects our body, we act in an out-ofsubject experience; we feel the effect of the presence of the urban heritage on us. Human body and heritage body located beyond their physically recognizable and officially delimited borders, or which meet in the extension of their spirits, affections and impressions when they cross. This ever so brief choreography we danced together can help understand the aestheticpolitical relationship of an artistic practice founded on the sensitive world, whose proposals encourage the multiplicity of micropolitical manifestations.

The issue of the relations between art and politics has recently been revived in the specific context of artistic practices with renewed urgency and radicalism given the serious world situation. But now, the focus is less on the works and their challenge to problematize the art system itself, as in the 1960s, and more on the following questions: how to resist the corruption of the creative power in art, its micropolitical power? Beyond the institutional scope of art, how can artistic strategies intervene in social life, establishing spaces for experimentation processes, their proliferation, their becoming? And even more radically, how can we contribute to unlock the creative power from its confinement in art? (Rolnik, 2018, p. 130, our translation) ${ }^{9}$.

As creative artists, these inquiries must inhabit our imagination on a daily basis, and the fragment-event here discussed may move us towards the creation of a shared action of the body.

In the article Programa performativo: o corpo-em-experiência [Performative Program: The body-in-experience], Eleonora Fabião (2013) points out her interest in reflecting on how the performative program ${ }^{10}$ has been informing artistic and pedagogical works. She also reports her experiments with programs as meeting places and mediations (Fabiáo, 2013, p. 9), observing how performances can act as triggers for new performances. The fragment under discussion is part of an investigation that aims to understand how the programs, as described by Fabiáo, can act as an element of exchange and dialogue within groups, and between artists and their surroundings. The programs should be performed according to the needs and findings of the research on site, broadening the concept of the actual program and of the urban space and gradually delivering the necessary tools so that the group can create, on site, its own programs. As such, we discuss the 
performative program as a way to, first, encounter the Other, and, second, to approach Lygia Clark's proposals, suggesting to the Other the possibilities of this same tool-action to produce active cuts in the world and to develop for himself a new infinity of performative programs for his own subjectivity, in favor of his potency of life. The body as an agent of language transformation, which rewrites history by interconnecting individual contents, memories and social aspects, and that understands that there is no single engine of history. The relationship between these forces and powers is complex and stands on an entirely uneven floor. New contemporary possibilities shall arise that reveal the body as an organism that holds its historical presence.

\section{Situating Oneself Publicly: walking, stopping and encountering the other}

In 2002, Francesco Careri published the book Walkscapes: o caminhar como prática estética [Walkscapes: Walking as an aesthetic practice], in which he narrates the story of this aimless wandering as a way of perceiving the landscape, including aspects of the Situationist International ${ }^{11}$. He discusses walking in the city not only as a way of improving observational sensitivity, but as an autonomous, active and constructive form of art. The pedestrian's speech builds imaginary maps of the body according to the city and vice versa - we can no longer read one without the contiguity of the other. To recognize the city's real potential, we need an artistic project that mobilizes the individual and social bodies to experience playful-creative behaviors. The architect will no longer be a builder of isolated forms, but a cultural agent capable of conceiving environments that are completed by dissenting performative experiences. I believe in undisciplined arts, understanding the territory of the urban heritage as a relational and participatory site, "[...] with wide availability for indeterminacy and listening to the Other's project" (Careri, 2013 [2002], p. 172, our translation) ${ }^{12}$.

At the end of Walkscapes, Careri outlines his next book, which was released in Brazil in 2017, Caminhar e parar [Walking and Stopping], in which the author "[...] would like to talk no longer about walking to get lost [or just as an autonomous and active form of art], but about walking to encounter the Other, about the decision to stop and build a space of encounter between the different" (Careri, 2013 [2002], p. 172, our transla- 
tion $)^{13}$. It is precisely in this leap between one publication and another that the role of the cultural agent in participatory processes is understood. When the artist assumes the role of cultural agent, he readies himself to guide a poetic and non-functional action with the group's participation; he proposes to assume the same risks as the other participants and, rather than focusing on his private research, exchanges tools to build an indeterminate project of unknown results. In architecture and urban design projects, it is precisely the playful mobility of participatory dance and theater that can express the complexity of the project, which, in addition to housing needs, must relate the users' wishes to a constantly changing network of activators. To ensure that their wishes are always renewed, the authors of the projects must interact directly with the space and, on a 1:1 scale, constantly discover new ways of being with the world (Glissant, 1995 apud Careri, 2017, p. 57).

What Careri points out is the need that lies beyond the flattened map where everything can be crossed, and the body is never territorialized; the need to engage in creating paths, managing the construction of spaces for gatherings. This civic art, as the author calls it, may expand its dimension if directly correlated to the urban context in which it exists.

The opening text of the recently published book $O$ teatro como experiência pública [Theater as a Public Experience ${ }^{14}$, written by Óscar Cornago (2019), one of its editors, La escena como marco público: ejercicio de reflexión en tres tempos [The Scene as a Public Landmark: Reflection exercise in three stages], as the name suggests, is a reflection on the public dimension of contemporary performing arts, taking as its starting point the dialogical track of Jackson Pollock's production (1912-1956). By temporarily laying the tableau horizontally, in the late 1940s, so that his implicated body dripped the paint on the canvas, the American painter made room for displacements of the artistic practice as a way of inhabiting space. It is the procedural relationship of an artist immersed in the act of making, in an environment whose repertoire, memory, and spatial and affective dimension seemed as familiar as part of the game. "Transgressing the normative uses of art to place it in relation to other worlds that are not exactly artistic was a revolution in the way of building the public sphere" (Cornago, 2019, p. 22, our translation $)^{15}$. 
When thinking about the city scale, it becomes clearer that, in general, public spaces serve private interests. And, because of this coalition, which seems more efficient, public space is confused with easy access to shopping mall consumption, or with frequenting safe streets and squares that require tacit authorization for circulation. This also occurs with urban heritage, which, although already listed as a historic site, cannot be considered public just because it is physically accessible by a crowd authorized to passively participate in its events. If this crowd is not heterogeneous, nor able to reprogram this space from the coexistence of their interests, it is impossible to affirm the public quality of collective action.

Thus, it no longer makes sense to reduce the concept of what is public as opposed to what is private. Even under the dimension of the theater scene, it is no longer possible to restrict the audience to the group that observes a scene, or to an absolute relationship with the present that disregards the many pages preceding the first one that opens the book and the ones written in the transformation of the public beyond that moment. This artistic practice, or project, implies coexistence and interconnects processes of exchange between work, surroundings and the collective - all crossed by their collective imaginations, personal memories, and historical memories of the place where these exchanges occur. A public activity that is still crossed by different artistic languages, whose effort to distinguish and name different specificities practiced between the 1970s and 1980s already seems superfluous considering the possibility of understanding them by their mobility, which blurs the boundary between fields. "Artistic modernity went from looking for the uniqueness of each language to entering a field whose compass was not to create a new language, but to position itself publicly in a different way by making art" (Cornago, 2019, p. 28, our translation) ${ }^{16}$.

This movement to raise awareness about the public dimension of the environment is directly connected to the content of Paul Ardenne's book Un arte contextual: creación artística en medio urbano, en situación, de intervención, de participación [A Contextual Art: Making art in urban environment, situation, intervention, participation], in which the author presents an overview of artists who, since the $20^{\text {th }}$ century, have chosen to place their actions in the fabric of the concrete world, abandoning institutions and using devices that create unmediated relations between their works and reality. Therefore, he grouped, under the term contextual art, the creations that 
were anchored to circumstances and willing to weave, with reality, works designed to adhere to the world and its surprises (Ardenne, 2006, p. 22). Contextual art is all about creating situations that revisit contexts and reveal structures of power and power plays that have shaped an environment that is familiar only in appearance. It is an art inserted in a place that is at the same time fuel for the movement of the work-action itself, inscribing both in an embodied relationship. Running counter to the representation of symbols already apprehended from $19^{\text {th }}$-century realisms, contextual art aims to embody experiences of the encounter with what the real produces, becoming embedded in the latent reality [encarnarse] (Ardenne, 2006, p. 12). To become public would therefore be to embody the dimension of an environment that only occurs with the encounter.

Who, then, might this artist be who understands reality as the sum of circumstances with which he or she intends to operate or to invite a group to operate? Who produces events and wonders how gestures that require authentic contacts with the Other (or with the surroundings) occur. An artist who weaves this network; before the artist as a creator, an artist as a connector. Artist as a being of proximity who inhabits "[...] a logic of implication that sees the work of art directly connected to a subject that belongs to the immediate history" (Ardenne, 2006, p. 13, our translation) ${ }^{17}$. Who opposes codified rules and develops counterprojects of imponderable consequences; who dances the uncertain and invites the Other to appropriate the urban space through the body. Who is this artist who understands that the current territories are inventions, historical constructions, discovered and recreated in the same movement and that the real is unassimilable as a unit? And that, "[...] given the impossibility of appropriating the real as a unit, we proceed by intermittences, impulses, mistakes, directed references and local infiltrations" (Ardenne, 2006, p. 41, our translation) ${ }^{18}$. Therefore, a new symbolic and sensitive dimension for the public sphere opens up, "[...] a phenomenon whose aesthetic condition determines the ways of being together $[\ldots]$ in relation to a past history and a present environment" (Cornago, 2019, p. 40, our translation) ${ }^{19}$.

Another example mentioned by Cornago is the possibility of transgressing the formal framework that makes the context visible, even if one preserves the classic framework of the theater scene, with an Italian stage and audience. The author analyzes Juan Domínguez's play Entre lo que ya 
no está y lo que todavia no está, which can be translated as Between what is yet to be and what is no longer - whose complete dramaturgy is published in the same book (Domínguez, 2019, p. 48-63). Domínguez, with no equipment other than a microphone to ensure the audibility of his voice, shares his own identity-in-construction with the audience. In writing the play, he made the fundamental choice of starting from a shared point with the audience and, for that, used the strategy of sharing the following question: what would you like to be forever beginners in? Then, he shares what his answer would be: to walk, which immediately becomes an invitation for everyone to forget how to do it and relearn together. Domínguez choreographs on the scene a gradual uprooting of himself that resembles the narrative of the protagonist of the novel $A$ paixáo segundo G.H. [The Passion According to G.H.], by Clarice Lispector, in a process of deterritorialization, or a kind of ciliary multiplication of himself. Starting by dismantling his name, Domínguez presents a dramaturgy whose actual words change meanings, with their original uses becoming something else. "But it is up to me to prevent myself from naming the thing. The name is an addition and prevents contact with the thing" (Lispector, 2009, p. 140). Between her name and her body, an echo, an abyss she does not allow herself to stare at, which awakens the same vertigo feeling from the maid's bedroom window that impresses G.H. In that abyss, the same accumulated silence of centuries, as if the voice and the words themselves expressed little. At the end of the narrative, the audience can approach the scene and return to their seats to have a popsicle together. Preserving a consequent silence. "But a silence now crossed not by the fictional memory of a creation process or by a shared reading activity, but by the remains, equally reinvented, of a life as a territory of exchange and imagination, game and desire" (Domínguez, 2019, p. 35 , our translation $)^{20}$.

After being accomplices in a journey while eating a popsicle together in silence, Cornago recalls Rose Braidotti's definition of the public as a place to be together in silence (Cornago, 2019, p. 33-34). It provokes “[...] the possibility of reinventing ourselves in public and transforming the public into a space of intimacy and collective desire, where fiction and reality coexist" (Cornago, 2019, p. 39, our translation) ${ }^{21}$. The collective experience occurs by bringing closer something that is shared, and the actions are born from this gathering that welcomes the uncertainties of the path. We can de- 
scribe the artist-connector as one who takes a stance, or the continuous attitude of finding possibilities for alternative constructions - the work of a lifetime. The artist as a connector is the one who chooses to position himself publicly as a way of inhabiting the world - suggesting, by the example above, that public is not exclusively about occupying shared spaces in the city -, but that translates into a way of relating, choosing to always be a beginner in being together.

\section{Firefly-knowledge-of-the-body}

Finally, it is worth going back the literary work Fahrenheit 451 by Ray Bradbury (2012 [1953]), a must-read in times when heritage burns while bodies are supplied with incombustible information. Dystopian reality in which the experience with the urban space and reading books are threats to the absolute world, and the only type of relationship to be built is with TV soap operas, in which one can have a role within the fictional family. The regime took over the city, the body, sex, Eros, and injected them into the consumption circuit. If the play is bad, if the movie was meaningless, encourage them with a theremin and a lot of noise; they will think they are reacting to the play, but it is only a tactile reaction to vibration (Bradbury, 2012 [1953], p. 85). Firefighters no longer put out the fire - the houses are all fireproof - but they burn books, because men resigned from history.

However, whenever the scenario is resumed or the totalitarian machine in action is designated, one must promptly mention the despite everything. Georges Didi-Huberman (2011), in Sobrevivência dos vaga-lumes [Survival of the Fireflies], quotes Ray Bradbury's text to define Italy's conjuncture in the 1970s, based on the article Vaga-lumes [Fireflies], written by Pier Paolo Pasolini. A letter that inspires fatalistic horror, revealing an even deeper fascism that supplanted the official (and only official) ruin of Mussolini's fascism. Attributing a definite victory to fascism would be the same as admitting the absence of possibility, no micropolitical insurrection that could come from the margins, walk through the lines, in parentheses, and act on the sidelines and multiply in rhizome. Despite the apocalyptic content of Pasolini's letter, his own artistic work is understood as a resistance to those looks that police uses, deprived of sensory vitality, and that legislate on those who move outside the order of circulation. The police choreography, as Lepecki points out, favors negotiation and consensus strategies, ac- 
customed to non-emancipatory policies, free from contradictions and disciplining. It is a choreo-police of intense luminosity, like that of a reflector that blinds and eliminates from sight the pulsating light of historical resistance and its artistry for transmutations of realities. But that does not mean that the quality of that second light does not survive. The preface by Paul B. Preciado for the book Esferas da insurreição: notas para uma vida não cafetinada [The Spheres of Insurrection: Suggestions for combating the pimping of life], by Suely Rolnik (2018), already announced the possible existence of a different left-wing spectrum, the same one that resisted in Fahrenheit 451 and formed new communities of re-existence, a subsoil, underground, under the skin, under the earth policy (Rolnik, 2018, p. 20). Under the dust of the city that rose into the air and fell with the war. After Montag, the protagonist of Bradbury's book, crosses the city border, a new way of using fire without the impulse of destruction fascinates him. He finds book-men, those who memorized whole books to protect them, gathered around a fire telling stories. Despite everything, the fireflies have formed their beautiful communities elsewhere. "Thus, there will be no dogmatic answer to this question, I mean: no general, radical, whole answer. There will be only signs, singularities, pieces, fleeting brightness, even if dimly luminous. Fireflies, to put it this way" (Didi-Huberman, 2011, p. 43, our translation) ${ }^{22}$. "And when they ask us what we are doing, we can say: we are remembering” (Bradbury, 2012 [1953] p. 198, our translation) ${ }^{23}$.

To recognize fireflies, one must see them dancing in the present of their survival. If only for a short time. Despite giving in to gravity, giving up verticality and bordering the floor. Despite moving very slowly (DidiHuberman, 2011, p. 45), like Francis Alÿs' magnetic feet ${ }^{24}$, creating a new urban fable when walking, and, with the residues and shards, composing a portrait of the lower city, of what is obscured on the ground. What appears, despite everything. What fell into the soil fissures, with thick memory, persists, dancing the very temporality of what today, among us, in extreme precariousness, survives and translates in new forms in its own decline.

Choreographing firefly-knowledge is possible and necessary. Hidden knowledge, ordinary, clandestine stories, intrinsic to the body, for a long time useless, making new monuments from realities submitted to censorship. Firefly-hyphen-knowledge. To turn these layers into nouns with the 
hyphen, as a way of opening up to metaphor instead of reading each word separately.

We can see the heritage and the relations with it in the considerable and complex thickness of its entangled temporalities. To dance landscapes of houses, arches in retaining walls, thin walls, from yards to the back of the houses, pre-existences, temporary uses and the relations with these designs and historical flows. Under the flash, to notice small histories in the big history. Memory as a protest capable of reshaping the future. Just as Charlotte Beradt collected dreams of the Third Reich, Svetlana Aleksiévitch (2018) put her ear to the ground, auscultated a new rhythm for the lost biographies of the last witnesses who saw and heard the fascists' iron boots making the earth agonize under their march ${ }^{25}$.

It is possible to provide the means for the emergence of fireflies, being the artist who weaves this network of resonance and recognition. An artist who, before being a creator, exists as a connector, or as a proximity being, that brings fireflies together. It is possible to vibrate with the possibilities of "[...] becoming fireflies and, thus, forming again a community of desire, a community of emitted flashes, of dances despite everything, of thoughts to be transmitted. Saying yes in the night full of flashes and not settling for describing the no of the light that dazzles us" (Didi-Huberman, 2011, p. 154155, our translation $)^{26}$. To walk, to stop, to come across the Other to whom you want to address new glimmers. To dance, despite everything, and choreograph this surviving matter made of luminescence.

\section{Notes}

1 Choay presents a panorama from the classicizing phase of the Quattrocento to the consecration of the historic monument, a moment marked symbolically by the writing of the Venice Charter (1964), a document recognizing the resumption of work related to protecting historical monuments in a public and internationally broader context. I can mention some researchers, such as Camillo Sitte (1843-1903), who focused his attention on the spatial organization of cities and dedicated himself to the pedagogy and study of urban morphology. As well as Gustavo Giovannoni's speech (1873-1974), who developed the term minor architecture, when recognizing domestic architecture as an integral part of the old urban ensemble. Then the idea of restoration as a discipline emerg- 
es, surpassing (theoretically) the attribution of a museological function to the old city, which finds no space to be incorporated into the dynamics of the living city. Giovannoni's speech, although still with some traces of this cityinventory, names urban heritage for the first time, integrating it with a general conception of space as territory, where the elements of the urban fabric are interconnected.

2 Originally, in Portuguese: "Essa travessia só pode ser tentada pela mediação de nosso corpo. Ela passa, precisamente, por um corpo-a-corpo: o do corpo humano com o corpo patrimonial. Ao primeiro, cabe mobilizar e pôr em alerta todos os seus sentidos, restabelecer a autoridade do tato, da cenestesia, da cinestesia, da audição e do próprio olfato, e recusar ao mesmo tempo a hegemonia do olho e as seduçóes da imagem fotográfica ou digital. Ao segundo, caberia um papel propedêutico: fazer que sejam apreendidas ou reaprendidas as três dimensões do espaço humano, suas escalas, articulaçôes, contextualização, na duraçáo de travessias, incursóes e percursos comparáveis ao saber de cor da memória orgânica, agora desprezados pela instituição escolar, que permitiam aos estudantes de outrora apropriar-se de seu patrimônio literário”.

3 Originally, in Portuguese: “[...] uma noção de política devidamente restaurada deve ter as características não da arte em geral, mas mais especificamente das artes efêmeras: a dança e o teatro".

4 Originally, in Portuguese: “[...] a construção de um ambiente que comporte os riscos implícitos aos mergulhadores nas camadas profundas do corpo, de onde emerge a expressividade, aos processos de exposição de si e ao outro, ao estar junto, à procura de um novo gesto, em um coletivo".

5 Originally, in Portuguese: “[...] uma arquitetura sensível, na qual os gestos tornam-se como que abrigos poéticos, '[...] onde habitar equivale a comunicar'”.

6 Originally, in Portuguese: "Nas subjetividades sob domínio do inconsciente colonial-capitalístico, reduzidas que são suas experiências como sujeito, prevalece uma micropolítica reativa: tende a impor-se em maior ou menor escala o movimento de conservação das formas de existência em que a vida se encontra corporificada no presente. É que, dissociada de sua condição de vivente e desconhecendo o processo contínuo de mutação próprio à dinâmica vital (dinâmica pulsional, no humano), a subjetividade vive a pressão dos embrióes de mundo como ameaças de desagregação de si mesma e de seu campo existencial, já que 'este mundo', aquele em que o sujeito habita e no qual se estrutura, é por ela vivido como 'o mundo', único e absoluto. Nessas condições, para 
recobrar um equilíbrio, o desejo agarra-se às formas estabelecidas, as quais busca conservar a qualquer custo. E quanto maior a desestabilização, mais veemente a subjetividade acastela-se no instituído e o defende com unhas e dentes, podendo chegar a altos níveis de violência para garantir sua permanência - incluindo a eliminaçáo concreta de qualquer outro que não seja seu espelho e cuja existência tenha por efeito abalar a fé na universalidade de seu mundo".

7 Originally, in Portuguese: "Juntos investigamos modos de criar corpo; modos de existir; de co-existir, de 'aprender a viver sobre as bases da precariedade".

8 Originally, in Portuguese: "Na experiência subjetiva fora-do-sujeito, o outro vive efetivamente em nosso corpo, por meio dos afetos: efeitos de sua presença em nós" and "ao se introduzirem em nosso corpo, as forças do mundo compóem-se com as forças que o animam e, nesse encontro, o fecundam".

9 Originally, in Portuguese: "No campo específico das práticas artísticas, é nesse contexto que a questão das relaçóes entre arte e política voltou recentemente à baila com renovada urgência e radicalidade diante da grave situação mundial. Mas agora, o foco passa a estar menos nas obras e seu desafio de problematizar o sistema da arte em seu próprio interior, como era nos anos 1960, e mais nas seguintes perguntas: como resistir à cafetinagem da potência de criação na arte, sua potência micropolítica? E, para além do âmbito institucional da arte, como estratégias artísticas podem intervir na vida social, instaurando espaços para processos de experimentação, sua proliferação, seus devires? E, mais radicalmente ainda, como contribuir para liberar a potência de criação de seu confinamento na arte?".

10 Eleonora Fabião suggests that we can operate the deconstruction of representation with the performative program, the driving force of her own experiences as a performer. Just as contextual art uses occasional statements, the performative program substantiates one of these accidental possibilities in a conceptually polished structure. The statement created expands the vocabulary of the social, political and historical material context by adhering to it.

11 The production of the Situationist International movement, founded in 1960, and whose intellectual clarity is due to Guy Debord (1931-1994), conceived Unitary Urbanism, which did not intend to remodel the city (as proposed by the modernists), but to combine art to the city's daily life, without distinguishing one from the other. The aim was to build situations or spaces of freedom so that the population could see the very conditions of alienation in which 
they lived, prevented from moving freely and following a standardized way of life.

12 Originally, in Portuguese: "[...] com uma ampla disponibilidade à indeterminação e à escuta do projeto do outro”.

13 Originally, in Portuguese: "[...] gostaria de falar não já do caminhar para perder-se [ou só como forma autônoma e ativa de arte], mas do caminhar para topar com o Outro, da decisão de deter-se para construir um espaço de encontro entre diversos".

14 The book $\mathrm{O}$ teatro como experiência pública [Theater as a Public Experience] was launched at the 2019 São Paulo International Theater Festival (MITsp).

15 Originally, in Spanish: "Transgredir los usos normativos del arte para ponerlo en relación con otros mundos no propiamente artísticos, supuso una revolución en la manera de construir la esfera pública”.

16 Originally, in Spanish: "La modernidad artística pasó de buscar la singularidad de cada lenguaje, a adentrarse en un terreno cuya brújula no era inventar un lenguaje nuevo, sino situarse publicamente de otro modo a través del hacer artístico”.

17 Originally, in Spanish: “[...] una lógica de implicación que ve la obra de arte directamente conectada a un sujeto que pertenece a la historia inmediata”.

18 Originally, in Spanish: "A falta de poder apropiarse lo real en bloque, procedemos por intermitencias, por impulsiones, por engaños, por guiños dirigidos e infiltraciones locales".

19 Originally, in Spanish: "[...] fenómeno cuya condición estética determina las formas de estar juntos [...] en relación a una historia pasada y un entorno presente".

20 Originally, in Spanish: "Pero un silencio atravesado ahora no por la memoria ficticia de un proceso de creación o por una actividad compartida de lectura, sino por los restos, igualmente reinventados, de una vida como territorio de intercambios e imaginación, juego y deseo".

${ }^{21}$ Originally, in Spanish: “[...] la posibilidad de reinventarnos en público y de transformar lo público en un espacio de intimidad y deseo colectivo, donde ficciones y realidades conviven".

22 Originally, in Portuguese: "Não haverá, portanto, resposta dogmática para essa questão, quero dizer: nenhuma resposta geral, radical, toda. Haverá apensas si- 
nais, singularidades, pedaços, brilhos passageiros, ainda que fracamente luminosos. Vaga-lumes, para dizê-lo da presente maneira”.

23 Originally, in Portuguese: "E quando nos perguntarem o que estamos fazendo, poderemos dizer: estamos nos lembrando".

${ }^{24}$ Francis Alÿs (1959) was born in Antwerp, Belgium, and currently lives in Mexico City. His performances are configured as a way of looking at the city from an artistic practice, in action. Cf. Artist's official website. Available at: <https://francisalys.com/>. Accessed on: Feb 20, 2020.

25 Didi-Huberman writes about the book Sonhos no Terceiro Reich [The Third Reich of Dreams: The nightmares of a nation, 1933-1939], by Charlotte Beradt (1907-1986), in which the author engages in the task of collecting a corpus of dreams, aiming to create a psychic panorama of totalitarianism in Germany, with its effects on the collective imagination by terrorizing sleep. Svetlana Aleksiévitch (Ukraine, 1948 - 2015 Nobel Prize winner) wrote the book As últimas testemunhas [Last Witnesses] (1985), a collection of accounts from people who were children during World War II. The excerpt used is part of Kátia Korotáieva's story, when she was thirteen years old. Cf. Aleksiévitch (2018).

26 Originally, in Portuguese: "[...] nos tornar vaga-lumes e, dessa forma, formar novamente uma comunidade do desejo, uma comunidade de lampejos emitidos, de danças apesar de tudo, de pensamentos a transmitir. Dizer sim na noite atravessada de lampejos e náo se contentar em descrever o náo da luz que nos ofusca”.

\section{References}

ALEKSIÉVITCH, Svetlana. As últimas testemunhas: crianças na Segunda Guerra Mundial. Tradução de Cecília Rosas. São Paulo: Companhia das Letras, 2018.

ARDENNE, Paul. Un arte contextual: creación artística en medio urbano, en situación, de intervención, de participación. Murcia: Cendeac, D. L., 2006.

BRADBURY, Ray. Fahrenheit 451: a temperatura na qual o papel do livro pega fogo e queima [1953]. Tradução Cid Knipel. 2. ed. São Paulo: Globo, 2012.

CARERI, Francesco. Walkscapes: o caminhar como prática estética [2002]. Tradução de Frederico Bonaldo. São Paulo: Editora G. Gili, 2013. 
CARERI, Francesco. Caminhar e parar. Tradução de Aurora Fornoni Bernardi. São Paulo: Editora G. Gili, 2017.

CHOAY, Françoise. A alegoria do patrimônio. Tradução de Luciano Vieira Machado. 4. ed. São Paulo: Editora Unesp; Estação Liberdade, 2006.

COELHO, José Teixeira. O que é ação cultural. São Paulo: Brasiliense, 1981.

CORNAGO, Óscar. La escena como marco público: ejercicio de reflexión en tres tiempos. In: CARNAGO, Óscar; FERNANDES, Silvia; GUIMARÃES, Julia (org.). O Teatro como Experiência Pública. São Paulo: Hucitec, 2019. P. 1741.

COSTAS, Ana Maria Rodriguez. Abrigos poéticos. Sala Preta, São Paulo, v. 11, n. 1, p. 2-16, 2011. Available at: <http://www.revistas.usp.br/salapreta/article/view/144692>. Accessed on: 20 Feb. 2020.

DESGRANGES, Flávio. A pedagogia do espectador. 3. ed. São Paulo: Hucitec, 2015.

DIDI-HUBERMAN, Georges. Sobrevivência dos vaga-lumes. Tradução de Vera Casa Nova, Márcia Arbex. Belo Horizonte: Editora UFMG, 2011.

DOMÍNGUEZ, Juan. Entre lo que ya no está y lo que todavía no está. In: CORNAGO, Óscar; FERNANDES, Silvia; GUIMARÁES, Julia (org.). O teatro como experiência pública. São Paulo: Hucitec, 2019. P. 48-63.

FABIÃO, Eleonora. Performance e precariedade. In: OLIVEIRA JUNIOR, Antonio Wellington de (org.). A performance ensaiada: ensaios sobre performance contemporânea. Fortaleza: Expressão Gráfica, 2011. P. 63-85.

FABIÃO, Eleonora. Programa performativo: o corpo-em-experiência. ILINX Revista do Lume, Campinas, n. 4, p. 1-11, 2013. Available at: <http://www.cocen.rei.unicamp.br/revistadigital/index.php/lume/article/view/27 6/256>. Accessed on: 20 Feb. 2020.

FORTIN, Sylvie; GOSSELIN, Pierre. Consideraçóes metodológicas para a pesquisa em arte no meio acadêmico. Art Research Journal, Natal, v. 1, n. 1, p. 1-17, 2014. Available at: $<$ https://periodicos.ufrn.br/artresearchjournal/article/view/5256>. Accessed on: 20 Feb. 2020.

LEPECKI, André. Coreo-política e coreo-polícia. ILHA, Florianópolis, v. 13, n. 1,

p. 41-60,

2013.

Available at: 
$<$ https://periodicos.ufsc.br/index.php/ilha/article/view/2175-8034.2011v13n12p41>. Accessed on: 20 Feb. 2020.

LISPECTOR, Clarice. A paixáo segundo G.H. Rio de Janeiro: Rocco, 2009.

PACHÁ, Paulo. Why the Brazilian far right loves the European Middle Ages. Pacific Standard, Santa Barbara, 2019. Available at: $<$ https://psmag.com/ideas/why-the-brazilian-far-right-is-obsessed-with-thecrusades>. Accessed on: 20 Feb. 2020.

ROLNIK, Suely. "Fale com ele" ou como tratar o corpo vibrátil em coma. In: CORPO, ARTE E CLÍNICA, 2003, Porto Alegre, UFRGS. Anais... Porto Alegre: $\quad 2003 . \quad$ Available at: <https://www.pucsp.br/nucleodesubjetividade/Textos/SUELY/falecomele.pdf>. Accessed on: 20 Feb. 2020.

ROLNIK, Suely. Esferas da insurreição: notas para uma vida não cafetinada. São Paulo: n-1 ediçóes, 2018.

VIGANÓ, Suzana Schmidt. As regras do jogo: a ação sociocultural em teatro e o ideal democrático. São Paulo: Hucitec; Mandacaru, 2006.

Juliana Raposo Semeghini is an architect and urban designer with a degree from the University of Campinas (UNICAMP). Currently she is pursuing a master's degree in the Performing Arts Graduate Program at UNICAMP.

ORCID: http://orcid.org/0000-0001-7959-6211

E-mail: jursemeghini@gmail.com

This original paper, translated by Amanda Cristina Pestana Prado and copyedited by Anthony Cleaver (Tikinet Edição Ltda.), is also published in Portuguese in this issue of the journal.

Received on July 29, 2019

Accepted on March 6, 2020

Editor-in-charge: Celina Nunes de Alcântara

This is an open-access article distributed under the terms of the Creative Commons Attribution License 4.0 International. Available at: <http://creativecom mons.org/licenses/by/4.0>. 